\title{
Przemiany układów ruralistycznych Mazowsza Wschodniego na przykładzie wybranych wsi powiatu siedleckiego
}

\section{Marlena Bierkat, Anna Długozima}

\begin{abstract}
STRESZCZENIE
Celem opracowania była identyfikacja głównych elementów układów ruralistycznych i określenie przemian zachodzących w kompozycji i zagospodarowaniu przestrzennym wsi mazowieckiej w XX i XXI w. Aby zrealizować założony cel wytypowano 5 poligonów badawczych, o ich wyborze zadecydowały następujące kryteria: przynależność administracyjna do powiatu siedleckiego, położenie na terenie historycznego Mazowsza Wschodniego, dostępność komunikacyjna, zasób dziedzictwa kulturowego, proweniencja układu. Pragmatyka badawcza objęła przegląd literatury dotyczący układów ruralistycznych, przekształceń obszarów wiejskich w Polsce oraz tożsamości wsi mazowieckiej. Dla każdej z wytypowanych wsi na podstawie map topograficznych, wizji terenowej oraz źródeł pisanych wytyczono cztery fazy obejmujące: okres międzywojenny, lata 1950-1960, czas transformacji ustrojowej oraz etap po przystąpieniu Polski do Unii Europejskiej. Okresy te uznane zostały za kluczowe dla struktury funkcjonalnoprzestrzennej i polityki przestrzennej w Polsce. Wyniki badań potwierdziły, że układy ruralistyczne uległy dużym zmianom, zarówno pod względem zagospodarowania jak i pełnionych funkcji. Za główne determinanty przekształceń wsi Mazowsza Wschodniego uznać należy zmianę stylu życia, słabnącą rolę rolnictwa oraz rozwój infrastruktury powiązany z dostępem do unijnych źródeł finansowania. Wiele ze zidentyfikowanych zmian negatywnie wpływa na tożsamość wsi, narażając ją na degradację przestrzenno-krajobrazową i utracenie pierwotnych cech. Artykuł prezentuje wyniki analiz podjętych w ramach pracy magisterskiej z 2016 r. na kierunku gospodarka przestrzenna.
\end{abstract}

\section{Wprowadzenie}

Przegląd socjologicznych [Grabski 1936; Gorlach 2004; Halamska 2011], ekonomicznych [Rosner 2007] i geograficznych [Bański 2002; 2011] interpretacji pojęcia wsi wskazuje na jego ogromną pojemność. Termin „wieś” obejmuje nie tylko styl życia, strukturę gospodarki, sposób zagospodarowania przestrzeni, związek z przyroda, ale jest to także kategoria symboliczna, mająca duże znaczenie w kulturze i życiu społecznym. W Polsce wieś jest ważnym elementem tożsamości narodowej i dziedzictwa kulturowego. Według GUS jest to "jednostka osadnicza o zwartej lub rozproszonej zabudowie $i$ istniejacych funkcjach rolniczych lub zwiazanych z nimi usługowych lub turystycznych nieposiadajaca praw miejskich lub statusu miasta". Wieś przez długi okres mocno wpisywana była w problematykę rolnictwa. Z tego powodu, mimo pewnych odrębności definicyjnych, większość autorów odwołuje się właśnie do jej rolniczych tradycji, uznając związek wsi z rolnictwem za jeden z najważniejszych wyróżników wsi [Podedworna 2006; Bański 2010; Wójcik 2012]. J. Tkocz [1998] formułując definicję wsi zwraca uwagę na jej atrybuty takie jak: granice wyznaczające terytorium, rozłóg ziemi i zagrody. Elementy te tworzą całość w przestrzeni, w której występują pewne więzy społeczne oraz uprawnienia prawne. 
Wieś szybko się zmienia. $Z$ tego powodu jest przedmiotem zainteresowania wielu dyscyplin naukowych, między innymi gospodarki przestrzennej. Z uwagi na charakter przemian dokonujących się na polskiej wsi, jej historię umownie dzieli się na dwa okresy: wsi tradycyjnej i współczesnej. Wieś tradycyjna w Polsce istniała do drugiej połowy XX w., od roku 1989 zaczyna się mówić o wsi współczesnej, co spowodowane było przemianami gospodarczymi [Nowak 2012]. Przełomem dla polskiej wsi był rok 2004 i wejście Polski do Unii Europejskiej. Wówczas polska wieś stała się głównym beneficjentem środków strukturalnych UE przeznaczonych na rozwój wsi i rolnictwa. Podkreślić należy, że przemiany wsi po 2004 r. to wynik współdziałania wielu czynników. Modernizacja doprowadza do zmiany form oraz struktur przestrzennych jednostek osadniczych. Badacze zgodnie twierdza, że w zagospodarowaniu polskiej wsi widoczne jest wypieranie funkcji rolniczej głównie na rzecz funkcji mieszkaniowej, przemysłowej, turystycznej oraz usługowej [Heffner 2010; Wilkin 2011; Halamska 2011; Rosner 2007]. Nowy program użytkowania zmienia jej oblicze: społeczne, gospodarcze, oraz architektoniczne [Szulc 1995].

Od lat 90. XX w. do czasów obecnych coraz silniej promowany jest wielofunkcyjny rozwój wsi [Jezierska-Thöle 2013]. Stan wiejskiej przestrzeni stale się pogarsza. Z raportu Przestrzeń życia Polaków [2014] wynika, że jej przekształcenia mają charakter żywiołowy, konfliktogenny, a skutki będą obciążeniem dla rozwoju Polski. Zagrożeniem dla tożsamości, funkcjonowania i kształtowania przestrzeni wsi jest urbanizacja. Na skutek postępu cywilizacyjnotechnicznego i transformacji społeczno-gospodarczej zmniejsza się dystans między życiem ludności w miastach i na wsiach, co przyczynia się do zacierania się wiejskiego krajobrazu: układów ruralistycznych, wyróżników wsi.

\section{Definicja układu ruralistycznego, jego rodzaje i elementy zagospodarowania}

Ruralistyka (łac. ruralis - wiejskość, wiejski; od rus, ruris - grunt, rola, wieś) to nauka zajmująca się planowaniem przestrzennym wsi oraz terenów rolnych, a także analizą historii powstawania i rozwoju form osadniczych na wsiach [Jarosz i Kamińska-Szmaj 2001]. Od tego określenia stworzono termin „układ ruralistyczny”, czyli układ przestrzenny wsi. W ustawie o ochronie zabytków i opiece nad zabytkami z 2003 r. [Dz.U. 2003 nr 162 poz. 1568] zdefiniowano pojęcie historycznego układu ruralistycznego jako: „przestrzenne założenie wiejskie, zawierajace zespoły budowlane, pojedyncze budynki i formy zaprojektowanej zieleni, rozmieszczone w układzie historycznych podziałów własnościowych i funkcjonalnych w tym sieci ulic i dróg". Z przytoczonej powyżej definicji wynika, że na układ ruralistyczny składa się układ zabudowań, pól oraz zieleni, który tworzy miejscowość. Narodowy Instytut Dziedzictwa powiela definicję ustawową uzupełniając, że podstawowymi wartościami układu ruralistycznego są elementy, które tworzą jego tożsamość i odrębność fizjonomiczną jednostki wiejskiej. W literaturze spotkać można także traktowanie układu ruralistycznego na równi z układem osadniczym [Studziński 2010].

Typy układów ruralistycznych, które ukształtowały się na ziemiach polskich to: przysiółek placowy, wielodrożnica, owalnica, szeregówka nadbrzeżna, szeregówka 
dwustronna (widlica), łańcuchówka, ulicówka, rzędówka (wieś sznurowa), okolnica, układ koncentryczny. J. Bański [2010] jako podstawowe kryteria determinujące układ morfogenetyczny wsi wymienia: układ pól, układ dróg, kształt siedlisk, układ przestrzenny rozłogów, planowość zabudowy, genezę miejscowości, stopień skupienia. Charakter i wygląd wsi tworzą elementy zagospodarowania przestrzennego oraz sposób ich wkomponowania w krajobraz. Podstawowym elementem zagospodarowania na wsi jest zagroda, czyli podwórko, w którego skład wchodzi dom mieszkalny i budynki gospodarcze. Układ zagród zwarty lub rozproszony stanowi o wyglądzie wsi [Szymańska 2013]. Oprócz siedlisk dużą rolę pełnią rozłogi, czyli układ pól. Istotną częścią zagospodarowania jest układ ulic w miejscowości, który wpływa na pierzeje ulic, czy osie widokowe [Studziński 2010]. Według W. Wieczorkiewicza [1995] elementy zagospodarowania wsi to: zabudowa historyczna, zabudowa mieszkaniowa, zabudowa przemysłowa oraz zorganizowana zieleń. W skład poszczególnych części wchodzą między innymi: siedliska z zabudową mieszkaniową i gospodarcza, tereny uprawowe, tereny usługowe - place, rynek, obiekty sakralne oraz budowle użyteczności publicznej.

Z uwagi na przynależność powiatu siedleckiego do historycznego Mazowsza tamtejsze układy ruralistyczne mają cechy tożsame dla mazowieckiej wsi. „Kanon przestrzenny” wsi tego regionu tworzą: regularne układy pól uprawnych (ułożonych prostopadle do drogi), przyzagrodowe, przydrożne i śródpolne pasy zieleni, ogławiane wierzby wzbogacające wizualnie krajobraz oraz zabudowa w postaci liniowej [Zaniewska, Pawłat-Zawrzykraj, Gloza-Musiał 2000]. Układy ruralistyczne Mazowsza najczęściej przybierały formę ulicówki, z charakterystyczną zwartą zabudową po obu stronach głównej drogi, gdzie centrum miejscowości stanowił mały plac [Szulc 1995]. Do rozwoju tego typu morfogenetycznego wsi mazowieckiej przyczyniły się cechy związane z położeniem, czyli krajobraz staroglacjalnych nizin, z bezjeziornymi równinami [Kondracki 2009]. Główny krajobraz wsi tworzyły chałupy chłopskie [Szmit bd.]. Były to obiekty drewniane, do formowania ich ścian używano masy glinianej, dach zazwyczaj kryty był słomą. Chałupy często bielono bądź malowano na jasnoniebiesko, ramy okienne czy drzwi były w kontrastowych kolorach. Domy rzadko zdobiono, a wnętrza izb były skromnie urządzone [Czerwiński 2001]. Siedlisko na wsiach Mazowsza przyjmowało typowy układ, czyli z przodu zlokalizowany był dom, dalej budynki gospodarcze oraz podwórko, które na końcu zamykała stodoła. Przed budynkiem mieszkalnym znajdował się przedogródek, a na tyłach siedliska sad [Wiśniewska 1984]. Ważne miejsce w krajobrazie regionu zajmowały elementy sakralne lokalizowane wzdłuż historycznych dróg (kapliczki, krzyże). Ponadto, wyróżnikiem przestrzeni wsi mazowieckiej były fasady i wieże świątyń widoczne z daleka. Istotnym motywem wpisanym w mazowiecki krajobraz były także dwory i pałace wraz z towarzyszącymi im parkami [Fortuna-Antoszkiewicz, Kimic 2007]. Parki dworskie położone były na przedpolach wsi, były rozległe i często w ich układ wkomponowane były obiekty wodne. Ważną rolę w kształtowaniu wyglądu wsi miała roślinność, szczególnie ważne jest w tym przypadku nawsie, które na Mazowszu najczęściej występowało w formie placu ozdobionego małą architekturą i roślinnością [Fortuna-Antoszkiewicz, Kimic 2007]. 


\section{Układy ruralistyczne w XX i XXI wieku w powiecie siedleckim}

Typowe wsie siedleckie na początku XX w. były w większości małe, liczące od 20 do 40 zagród. Najczęściej lokalizowano je przy rzekach, a układ zabudowy nie był ciasny. Pola ciągnęły się długimi wąskimi pasami, albo były ułożone w szachownicę. Ze względu na kształt układu ruralistycznego wsie w powiecie siedleckim można podzielić na 3 grupy - zachodnia, środkową i wschodnią [Zaborski 1926]. W okolicach miasta Siedlce oraz na południowy-zachód od niego przeważały tzw. ulicówki. Na wschód od miasta ulokowały się niewielkie wsie bezkształtnie zabudowane, zazwyczaj były to wsie szlacheckie. Na wschód od źródeł Liwca natomiast przeważały wsie z obustronną zabudową ulicy i bardzo długie, podobne do tych z zachodniej części powiatu, jednak zdecydowanie od nich większe. Na rycinie 1. przedstawiono orientacyjny rozkład przeważających typów wsi na danym obszarze według podziału J. Mikulskiego [1935]

Ryc. 1. Mapa przedstawiająca pola badawcze na tle powiatu siedleckiego z orientacyjnym wskazaniem przeważającego typu wsi z początków XX wieku w danej gminie

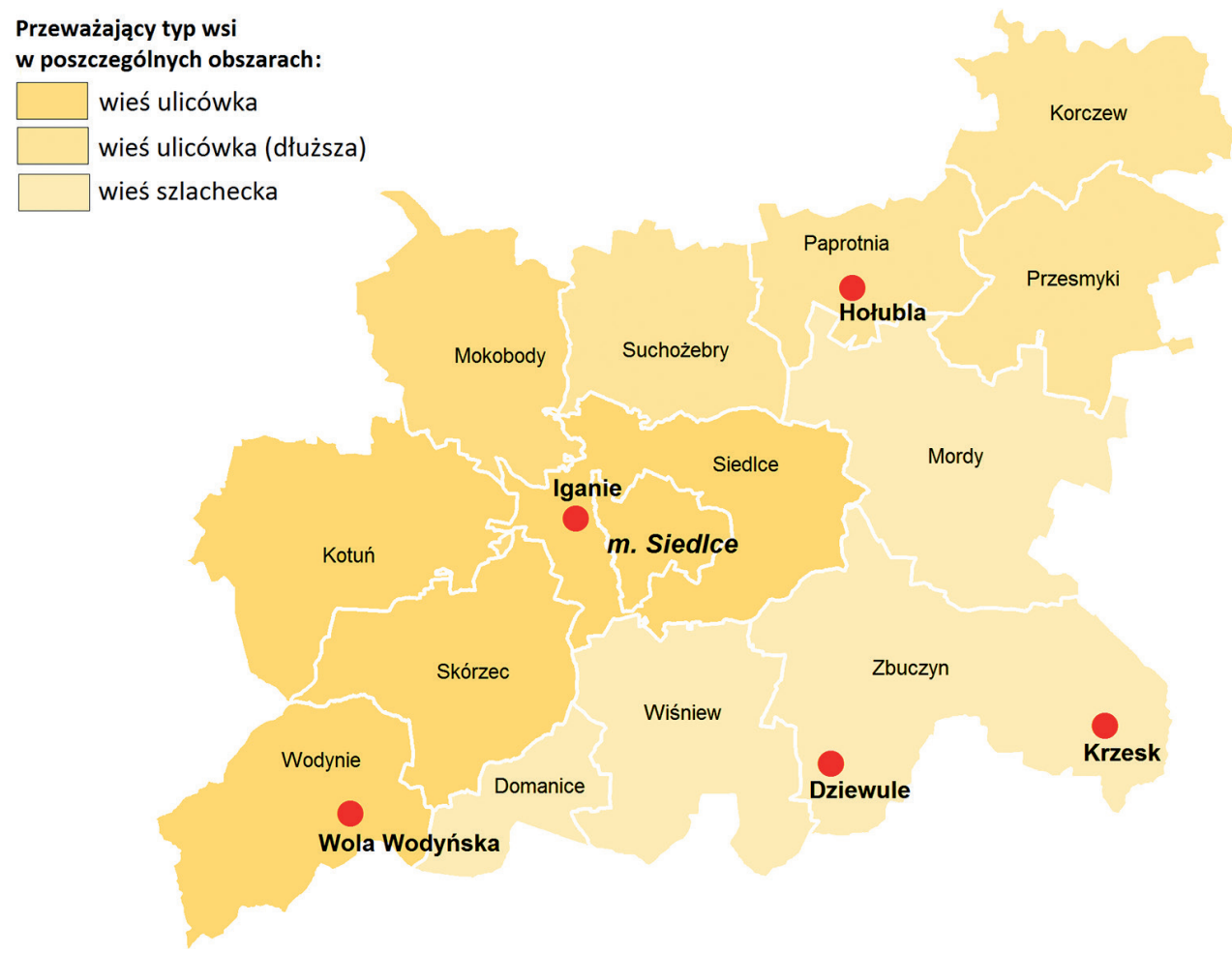

Źródło: opracowanie własne na podstawie http://mapsgoogle.com 
Spośród ponad 300 wsi siedleckich do badań wybrano 5 jednostek osadniczych. Są to: Dziewule, Iganie, Hołubla, Krzesk, Wola Wodyńska (ryc. 1). O ich wyborze zadecydowały następujące kryteria: przynależność administracyjna do powiatu siedleckiego, położenie na terenie historycznego Mazowsza Wschodniego, położenie w relacji do miasta Siedlce, dostęp do infrastruktury komunikacyjnej, dziedzictwo kulturowe, okres ukształtowania układu ruralistycznego (proweniencja).

\section{Dziewule - gmina Zbuczyn, liczba ludności: 775 [GUS 2011]}

Wieś położona jest w południowej części powiatu siedleckiego. Wybrano ją do badań ze względu na położenie przy linii kolejowej Łuków - Siedlce oraz z powodu utraconego dziedzictwa kulturowego. W XIX w. Dziewule były siedzibą gminy, w miejscowości istniał dwór, a przy nim karczma oraz browar, (ryc. 2).

\section{Ryc. 2. Układ przestrzenny Dziewul: A - 1937 r., B - 2016 r.}

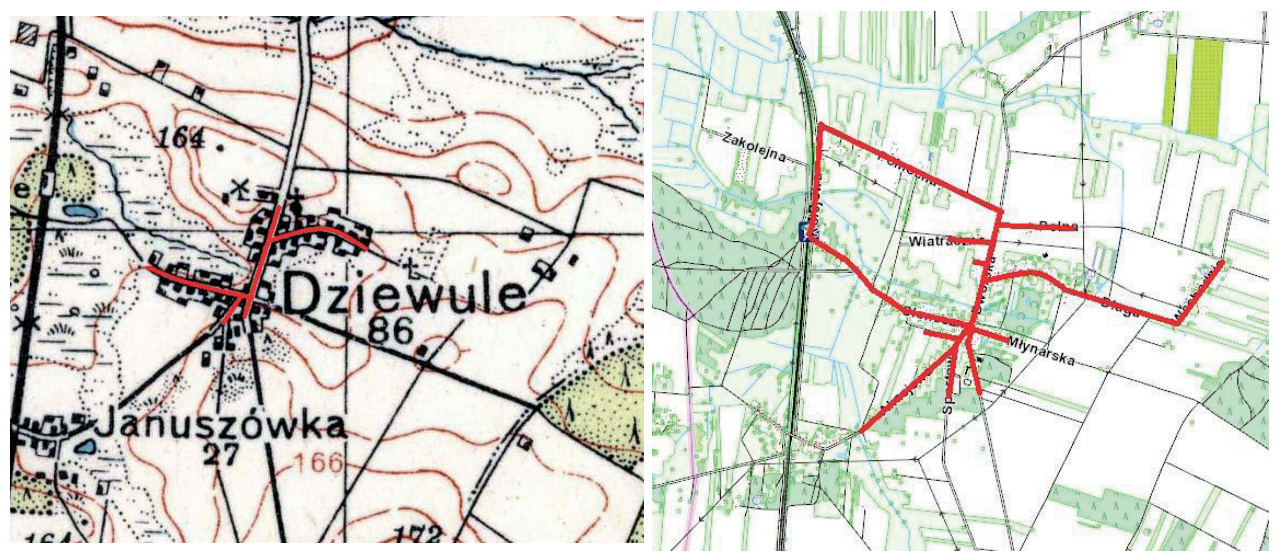

*Kolorem czerwonym zaznaczono układ drożny wsi Źródło: A: http://www.mapywig.org, B:http://mapy.geoportal.gov.pl

W okresie międzywojennym układ przestrzenny wsi charakteryzowało podobieństwo do widlicy oraz wielodrożnicy, gdyż centrum było gęsto zabudowane i rozwidlało się w kształcie litery " $\mathrm{V}^{\prime \prime}$, jednak na obrzeżach przy drogach występowały pojedyncze zabudowania nieregularnie położone względem dróg głównych. Zabudowa skupiała się w dwóch rejonach, oddzielonych strumykiem. W latach 30. XX w. szkoła podstawowa funkcjonowała w prywatnym domu, w 1939 r. została przeniesiona do nowego budynku. Budowlami wyróżniającymi się w Dziewulach był wiatrak typu koźlak, z końca XIX w. oraz młyn. Ważnym obiektem była również kapliczka z obrazem Matki Boskiej, która od XVIII w. stała przy gościńcu Zbuczyn - Łuków. Układ siedliska wpisywał się w kanon obowiązujący na Mazowszu. Z przodu zlokalizowany był dom, dalej budynki gospodarcze oraz podwórko, 
które na końcu zamykała stodoła. Przed budynkiem mieszkalnym usytuowany był ogródek. Dominującą funkcją było rolnictwo. W miejscowości funkcjonował jeden sklep, brakowało jednak terenów użyteczności publicznej.

W latach 1950-1960 układ przestrzenny Dziewul ewoluował w kierunku wielodrożnicy. W centrum wsi, a także na kolonii przybyło zabudowań. Wieś zaczęła się rozbudowywać w kierunku kolejnej miejscowości - Januszówki. W Dziewulach nadal funkcjonował wiatrak, który był dominantą we wsi oraz młyn elektryczny, w latach 60. powstała Ochotnicza Straż Pożarna i remiza strażacka.

W okresie transformacji ustrojowej układ przestrzenny coraz bardziej rozbudował się na koloniach. W centrum układu zabudowa była dogęszczana, w sposób spontaniczny powstawały kolejne, nieregularnie sytuowane ulice, przyczyniając się do fragmentaryzacji terenów otwartych. W latach 1986-1988 wybudowano kościół katolicki, przy którym w 2000 r. założono cmentarz. Koniec lat 80. oraz początek 90. XX w. to także rozbudowa dawnego budynku Spółdzielni Kółek Rolniczych i przekształcenie go w świetlicę wiejską oraz wybudowanie boiska dla lokalnego klubu piłkarskiego. W 1999 r. rozpoczęto budowę nowej szkoły. Dawny wiatrak koźlak został rozebrany, a młyn elektryczny przestał funkcjonować. Dominującą funkcję pełniło rolnictwo i mieszkalnictwo.

Współcześnie układ wsi to wielodrożnica, która wciąż się rozbudowuje. Dzięki środkom z funduszy europejskich zamieniono niszczejący budynek dawnej szkoły podstawowej w nową strażnicę z salą świetlicy wiejskiej i sklepem. W Dziewulach powstały chodniki, poprawiono stację i poczekalnię PKP. W 2005 r. otwarto nową szkołę, w kolejnych latach zadbano o jej otoczenie poprzez stworzenie placu zabaw, boisk, altany, przedszkola oraz sali gimnastycznej. Obecnie wieś głównie pełni funkcję mieszkaniową z małym udziałem funkcji rolniczej.

\section{Hołubla - gmina Paprotnia, iczba ludności: 580 [GUS 2009]}

Wieś Hołubla oddalona jest od linii kolejowej oraz głównych arterii komunikacyjnych. Charakteryzuje się zabytkowym układem ruralistycznym pochodzącym z XVI w., który jednak nie jest wpisany do rejestru zabytków. Wieś została wybrana do badań ze względu na swoje peryferyjne położenie względem miasta Siedlce oraz związany z tym mniej dynamiczny rozwój tego terenu, (ryc. 3).

W okresie międzywojennym układ przestrzenny wsi to charakterystyczna widlica. W Hołubli występowała gęsta, zwarta zabudowa, koncentrująca się przy głównych ulicach. We wsi przeważały domy szerokofrontowe, dwutraktowe. Na początku XX w. wiele domów ozdobionych było dekoracyjnym szczytem, listwami podokapowymi, nadokiennikami czy gankami. Szkoła istniała od 1880 do 1943 r. i działała w małym budynku, dodatkowe sale do nauki były wynajmowane w prywatnych domach. Od roku 1922 istnieje Ochotnicza Straż Pożarna, która zapoczątkowała budowę remizy i domu ludowego. We wsi znajdował się także kościół z 1750 r., który na początku XX w. został wyremontowany. W latach 1940-1942 postawiono nowy budynek kościoła. We wsi znajdowało się dużo kapliczek przydrożnych. 
Ryc. 3. Układ przestrzenny Hołubli: A - ok. 1937 r., B - 2016 r.

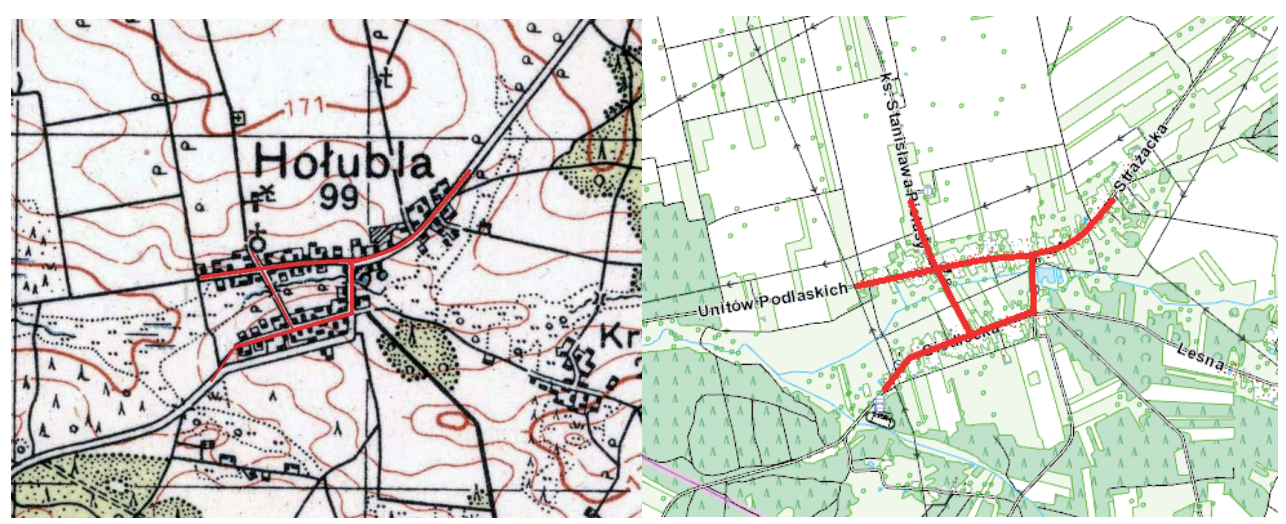

*Kolorem czerwonym zaznaczono układ drożny wsi Źródło: A: http://www.mapywig.org, B:http://mapy.geoportal.gov.pl

Hołubla była wsią chłopska, która pełniła funkcje rolnicze.

W latach 1950-1960 wieś nie zmieniła swojego układu przestrzennego, zabudowa rozwijała się wzdłuż istniejących dróg. Widoczny rozwój zabudowy występował na wschodzie i zachodzie wsi. Dotychczasowe budynki drewniane po wojnie zostały zachowane, nowo powstające domy były murowane i piętrowe. We wsi funkcjonowała szkoła, kościół oraz sklepy. Niwowy układ pól nie został zachowany.

Transformacja ustrojowa nie przyniosła większych zmian. Nowych zabudowań powstało niewiele, głównie zastępując stare domy. Wznoszone wówczas budynki były murowane, piętrowe, nie nawiązywały do lokalnych tradycji budowlanych. W latach 70 . XX w. w Hołubli powstał nowy dom ludowy, z salą kinową. Przeprowadzono remont świetlicy, remizy strażackiej oraz szkoły podstawowej. Rolnictwo stanowiło główną funkcję wsi i podstawowe źródło utrzymania ludności. Obecnie we wsi wciąż zostaje zachowany historyczny układ ruralistyczny w formie widlicy. Nowe budownictwo stanowi niewielki odsetek w strukturze terenów zainwestowanych. Przeważają domy wznoszone w okresie transformacji oraz zabudowania drewniane. Zabudowania gospodarskie występują w większości siedlisk. Wejście Polski do Unii Europejskiej pozwoliło na uzyskanie funduszy na budowę i modernizację budynków publicznych we wsi takich jak szkoła, czy świetlica wiejska. Otwarte zostało także publiczne przedszkole oraz powstał zbiornik retencyjny. W 2013 r. wieś zyskała oczyszczalnię ścieków oraz podłączenie do kanalizacji ogólnospławnej. Powstało także nowoczesne boisko piłkarskie i stacja paliw. Hołubla pełni funkcję wsi rolniczej, gdzie duży procent ludności utrzymuje się z rolnictwa. 


\section{Iganie Stare, Iganie Nowe - gmina Siedlce, liczba ludności - 1595 [GUS 2009]}

Iganie Stare i Iganie Nowe sąsiadują bezpośrednio z miastem Siedlce, znajdując się pod presją inwestycyjną tego ośrodka. Wsie leżą przy trasie Siedlce - Warszawa. W Iganiach Starych znajduje się dwór pochodzący z pierwszej połowy XIX w. Wieś wybrano do badań ze względu na bezpośrednie sąsiedztwo z miastem Siedlce, które wpłynęło na rozwój miejscowości i ukształtowanie jej charakteru, (ryc. 4).

\section{Ryc. 4. Układ przestrzenny Igań: A - 1937 r., B - 2016 r.}

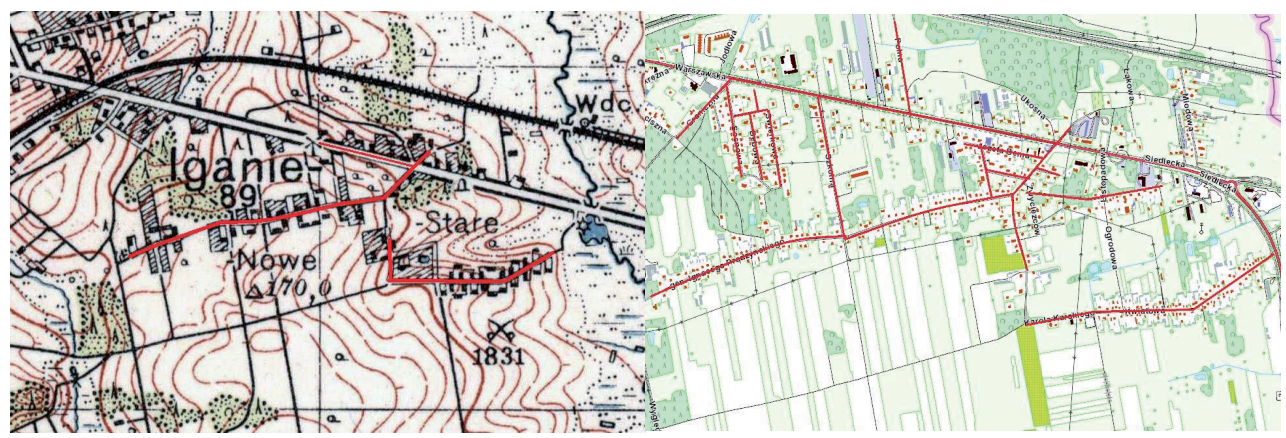

*Kolorem czerwonym zaznaczono układ drożny wsi Źródło: A: http://www.mapywig.org, B: http://mapy.geoportal.gov.pl

Układ przestrzenny w 20-leciu międzywojennym przypominał ulicówkę, dwie części wsi dzielił trakt z Warszawy do Siedlec, główna część miejscowości znajdowała się po jego południowej stronie. W ówczesnym czasie w Iganiach większość domów to obiekty drewniane. Zagrody we wsiach różniły się od charakterystycznych zagród wsi siedleckiej, gdyż siedliska usytuowane były gęsto na wąskich parcelach. W 1931 r. wybuchł pożar, a odbudowa domów wpłynęła na zmianę układ wsi. W Iganiach Starych funkcjonował dwór oraz wiatrak. W 1918 r. w Iganiach Nowych powstała szkoły podstawowa, a w 1938 zapoczątkowano budowę nowego obiektu. We wsiach występowała duża liczba kapliczek i krzyży. Grunty wsi wykorzystywano rolniczo. Przez wschodnie tereny Starych Igań płynie rzeka Muchawka, przy której istniał zbiornik z groblą, spełniający także funkcje rekreacyjne.

W latach 1950-1960 układ przestrzenny wsi Iganie Stare to ulicówka z gęstą zabudowa, zaś układ Igań Nowych to ulicówka transformująca w widlicę, gdzie zabudowa jest mniej zagęszczona. Po północnej stronie trasy Warszawa - Siedlce widoczny był wzrost liczby zabudowań. Nowe domy, były przede wszystkim murowane, jednak widoczny był duży udział domów drewnianych, szczególnie w części Igań Starych. Po wojnie majątek sprzedano, a dwór popadał w ruinę. $\mathrm{W}$ miejscowości funkcjonował młyn wodny, wiatrak został rozebrany. W 1958 r. rozpoczęto budowę nowej, murowanej szkoły. Usługi na tym terenie świadczyło kilka sklepów spożywczych. 
W okresie transformacji układ przestrzenny wsi Iganie Nowe coraz bardziej się rozbudowywał i uwidoczniała się widlica. Iganie Stare to gęsto zabudowana ulicówka. Widoczny jest wzrost liczby zabudowań. Rozbudowa wsi uzasadniona jest sąsiedztwem miasta Siedlce i poszukiwaniem przez mieszkańców miasta bardziej ustronnego miejsca zamieszkania. Większość istniejących domów to zabudowa murowana, piętrowa, jednak duży udział, szczególnie w Iganiach Starych, mają dawne domy drewniane. Dwór popadł $\mathrm{w}$ ruinę i pozostaje niezagospodarowany, a park został przeznaczony na działki mieszkaniowe. Widoczne jest zanikanie funkcji rolniczej, która zostaje wypierana przez funkcję mieszkaniową. W Iganiach Nowych wybudowano nowy budynek szkolny. We wsiach funkcjonuje urząd pocztowy, liczne sklepy, usługi transportowe, brak jest świetlicy, która pozwoliłaby na integrację mieszkańców. Zmienia się struktura zatrudnienia z rolnictwa na przemysł i usługi.

Obecnie Iganie Stare zachowują układ ulicówki, jednak Iganie Nowe zamieniły się w wielodrożnicę. Następuje ciągły rozwój wsi, na północ od drogi krajowej nr 2 powstały nowe osiedla w formie zabudowań szeregowych, które są oznaką bliskości miasta i osiedlania się na terenie wsi mieszkańców Siedlec. W Iganiach Starych zidentyfikować można znaczny udział drewnianych domów, upływ czasu jest tu mniej widoczny. Dwór jest nieużytkowany i niszczeje. Przy szkole została otwarta hala gimnastyczna oraz punkt przedszkolny. Na terenie Igań zlokalizowanych jest również kilka sklepów spożywczych oraz poczta. Funkcja rolnicza na terenie wsi praktycznie zanikła. Wsie pełnią fukcję mieszkaniowo-usługową. Przy drodze krajowej nr 2 powstają punkty usługowe.

\section{Krzesk Królowa Niwa, Krzesk Majątek - gmina Zbuczyn, liczba ludności: 818 [GUS 2009]}

Krzesk położony jest na południowo-wschodnich krańcach powiatu, na północ od drogi krajowej Warszawa - Terespol. W XIX w. w Krzesku powstał dwór z parkiem, który obecnie uchodzi za jeden z najlepiej zachowanych w tej części Polski. Wieś została wybrana do badań ze względu na istniejący zespół dworsko-parkowy (wpisany do rejestru zabytków pod nr. A-14/56) oraz swoje położenie, (ryc. 5).

Na początku XX w. układ ruralistyczny Krzeska Królowa Niwa to typowa ulicówka, gdzie zabudowania położone były po obu stronach dróg, a pola uprawne rozciągały się za zabudowaniami. Krzesk Majątek powstał jako założenie dworskie, które później zaczęło ewoluować w widlicę i rozgałęziać się w postaci litery „,V”. W siedlisku znajdował się dom, zabudowania gospodarcze oraz ogródek. Zabudowa to drewniane, parterowe domy, w większości bielone. Przy dworze istniał zadbany park. Naprzeciw dworu stały tzw. czworaki dla służby dworskiej. Pod koniec XIX w. przy dworze zaczęła też funkcjonować gorzelnia. W 1919 r. w Krzesku Majątku, na ziemi należącej do dworu, zakończono budowę kościoła. Od 1925 we wsi działa Ochotnicza Straż Pożarna, w 1927 r. powstała szkoła, swoje usługi oferowały dwa sklepy oraz poczta. Krzesk Królowa Niwa od czasu zaborów był gminą. 
Ryc. 5. Układ przestrzenny Krzeska: A - 1937 r., B: 2016 r.

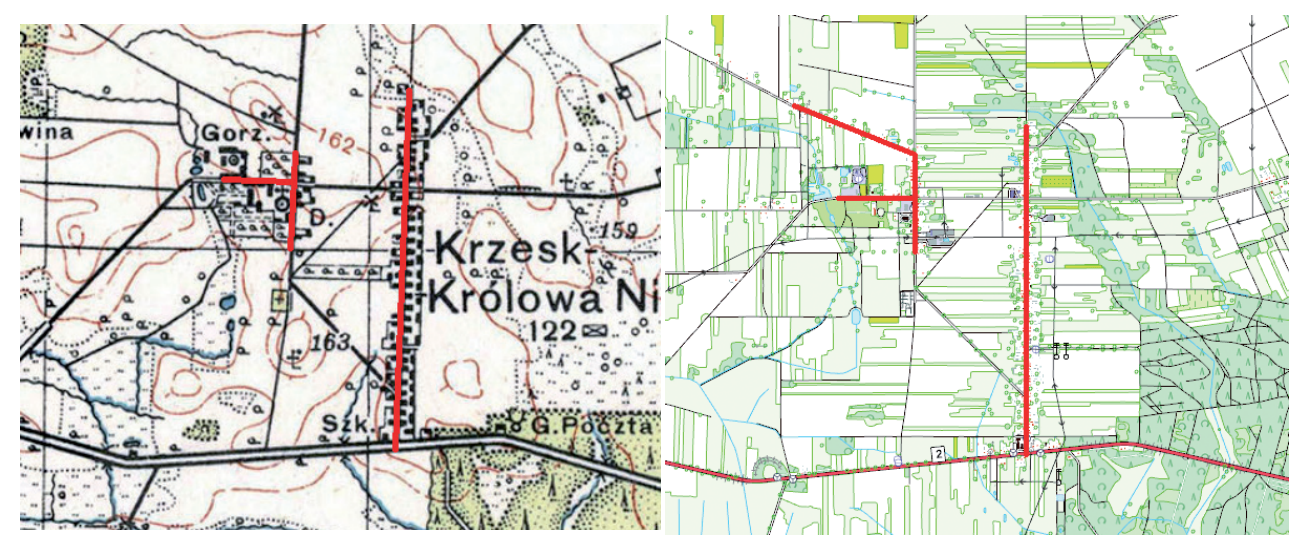

*Kolorem czerwonym zaznaczono układ drożny wsi

Źródło: A: http://www.mapywig.org, B: http://mapy.geoportal.gov.pl

W latach 50. XX w. w Krzesku Majątku układ ruralistyczny zaczął ewoluować w kierunku widlicy, natomiast w Królowej Niwie rozwijał się dalej wzdłuż jednej drogi, zabudowa bardziej się zagęściła. Naprzeciwko pałacu zaczął funkcjonować sklep, przy którym istniała również gospoda. W Krzesku Królowej Niwie działały dwa sklepy oraz kiosk. Szkoła podstawowa była rozbudowywana, pobudowano także dom ludowy. W Majątku budowano świetlicę wiejska, która nie została wykończona. Park przy pałacu otwarto dla wszystkich, został on pozostawiony bez opieki i zieleń na jego terenie rosła w niekontrolowany sposób. Krzesk Królowa Niwa dalej pełnił funkcję gminy. Majątek został rozparcelowany po wojnie, $\mathrm{w}$ wyniku reformy rolnej dwór został upaństwowiony. W dworze mieściła się siedziba gminy, milicja, poczta oraz gminna spółdzielnia.

W okresie transformacji ustrojowej w niewielkim stopniu wzrosła liczba zabudowań. W 1990 r. dwór wraca do rąk właścicieli, którzy zaczynają odrestaurowywać budynek. Park dworski jest zaniedbany, zachowane zostały dawna aleja lipowa, szpalery grabowe, figurka Matki Boskiej. W Krzesku Królowej Niwie w domu ludowym funkcjonuje świetlica wiejska. Budynek szkoły rozbudowano, dobudowano salę gimnastyczną. Od lat 70. XX w. działa ośrodek zdrowia, apteka i poczta. W 1993 r. gorzelnia została przejęta przez siedlecki Polmos i uruchomiono w niej produkcję.

Współcześnie układ ruralistyczny miejscowości nie uległ dalszym przekształceniom. Procesowi degradacji podlega układ siedlisk we wsi. Budynki drewniane, kryte strzechą zastąpiono okazałymi, murowanymi budynkami mieszkalnymi oraz gospodarczymi. Zmieniła się estetyka ogródków przydomowych i podwórek. W Krzesku nadal pozostało dużo budynków drewnianych, które zostały odnowione. Dwór dzięki zaangażowaniu właścicieli został odrestaurowany, jednak park dworski nadal wymaga nakładu pracy. Obecnie we wsi istnieje kilka sklepów, a także punkt kasowy banku, poczta została zamknięta, ośrodek zdrowia i apteka nadal funkcjonuja, a przy szkole działa punkt przedszkolny. 
Dzięki pomocy finansowej z funduszy europejskich zbudowano oczyszczalnię ścieków, system wodociągowy i kanalizacyjny. Krzesk pełni obecnie funkcje takie jak: mieszkaniowa, usługowa, rolnicza oraz kulturowa.

\section{Wola Wodyńska - gmina Wodynie, liczba ludności: 431 [GUS 2009]}

Wieś położona w gminie Wodynie, oddalona od miasta Siedlce o około 20 kilometrów, otoczonajest lasami. Miejscowośćzostała wybrana dobadańgłównie ze względu na unikatowy na tym obszarze typ wsi (łańcuchówka), swoje położenie oraz słabe skomunikowanie wsi z miastem Siedlce, (ryc. 6).

\section{Ryc. 6. Układ przestrzenny Woli Wodyńskiej: A - 1937 r., B: 2016 r.}

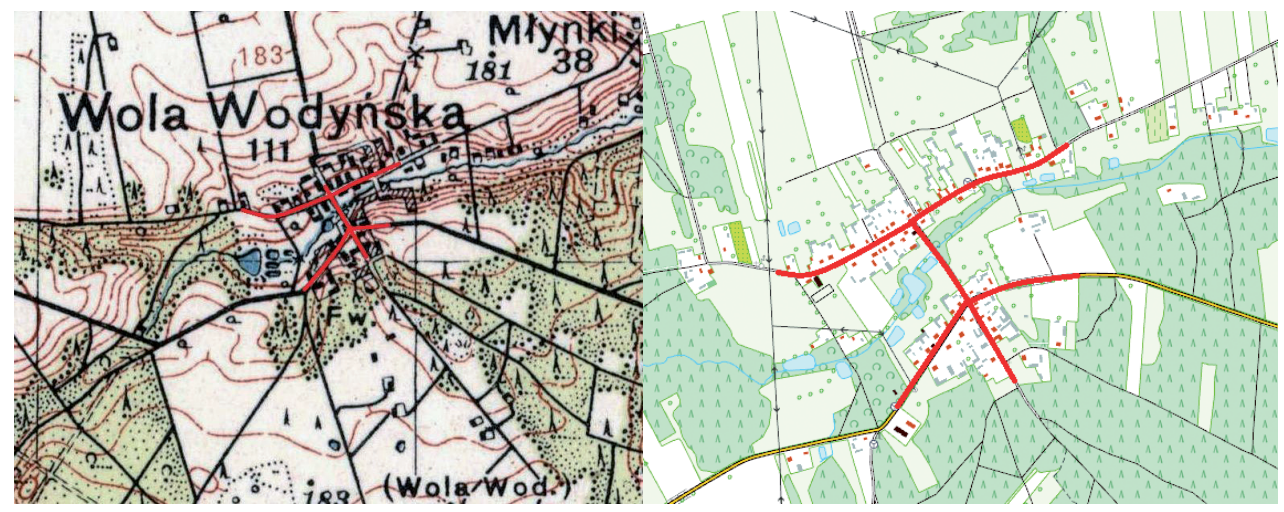

*Kolorem czerwonym zaznaczono układ drożny wsi

Źródło: A: http://www.mapywig.org, B: http://mapy.geoportal.gov.pl

Układ przestrzenny w okresie międzywojennym to łańcuchówka z dwiema głównymi drogami. Łańcuchówka była układem typowym dla obszarów wyżynnych i górskich, dlatego na ziemi siedleckiej Wola Wodyńska była unikatową wsią. Charakterystyczna we wsi była luźna zabudowa i przestrzeń publiczna występująca w centrum. Pomiędzy zabudową oraz za siedliskami rozmieszczone były pola uprawne, wieś otaczały lasy. W 1924 r. utworzono Ochotniczą Straż Pożarną i rozpoczęto budowę remizy. We wsi działała szkoła podstawowa, funkcjonująca w prywatnych domach, był także młyn. Przy drogach występowało dużo kapliczek, unikatowa była istniejąca do dzisiaj osiemnastowieczna, drewniana kapliczka brogowa z figurą św. Jana Nepomucena. W Woli Wodyńskiej istniał folwark i park dworski z kompleksem stawów, jeden zbiornik przeznaczony był na cele rekreacyjne. Wieś pełniła funkcję rolniczą. 
W latach 1950-1960 układ przestrzenny miejscowości rozwinął się w kierunku wschód - zachód, zachowując typ łańcuchówki. Wieś charakteryzowała luźna zabudowa z placem publicznym przy remizie strażackiej w centrum. Po wojnie majątek został rozparcelowany. We wsi funkcjonowała remiza strażacka wraz z domem ludowym oraz sklep spożywczy. W latach 60. wybudowano szkołę podstawowa, do której uczęszczali uczniowie klas I-IV. W 1955 r. młyn przekształcony został w elektryczny, gdyż nastąpiła wtedy elektryfikacja wsi. W czasie wojny we wsi zlokalizowano cmentarz wojenny, na którym pochowani zostali uczestnicy bitwy o Wolę Wodyńską z września 1939 r.

W okresie transformacji zdecydowaną większość stanowiły parterowe, drewniane domy, niewielki był udział domów murowanych. W 1993 r. oddano do użytku nowy Dom Strażaka, który był wykorzystywany również jako sala wiejska. Park podworski podlegał stopniowej dewastacji. Wieś pełniła funkcję rolnicza, a większość ludności wsi utrzymywała się z rolnictwa.

Współczesny układ wsi to łańcuchówka zbudowana z dwóch ciągów komunikacyjnych. We wsi występuje historyczny układ przestrzenny. Zabudowania w większości stanowią odnowione parterowe, drewniane domy, a siedliska charakteryzują się zabudową zagrodową. W 2008 r. szkoła podstawowa została zamknięta, grunty szkoły sprzedano, a w jej miejscu został otwarty dom seniora. Park podworski jest zaniedbany, oczekuje na rewaloryzację. W Woli Wodyńskiej otwarto gospodarstwo agroturystyczne ze stadniną koni. Wieś nadal wyróżnia się dużą liczbą krzyży i kapliczek przydrożnych. Obecnie wieś pełni funkcje mieszane, gdzie łączone są mieszkalnictwo, rolnictwo, usługi agroturystyczne.

\section{Przekształcenia i tendencje zmian we wsiach powiatu siedleckiego}

Wytypowanie czterech etapów rozwoju wsi w XX i XXI w. (okres międzywojenny, lata 50. i 60. XX w., okres transformacji ustrojowej oraz okres po przystąpieniu Polski do UE) dla 5 wsi powiatu siedleckiego, ich porównanie oraz skonfrontowanie z cechami tradycyjnej wsi mazowieckiej wskazuje na czytelne, niepokojące przekształcenia wsi w wymiarze fizjonomicznym (układ przestrzenny wsi, elementy zagospodarowania). Otrzymane wyniki potwierdzają ogólne trendy zmian zachodzących na polskiej wsi. W tabeli 1. przedstawiono główne czynniki, które determinują rozwój przestrzenny oraz zmiany $\mathrm{w}$ badanych układach ruralistycznych. Na rozwój wsi wpłynęła w największym stopniu dostępność infrastruktury oraz skomunikowanie $\mathrm{z}$ miastem. Skomunikowanie z miastem stanowiło czynnik determinujący w dużym stopniu rozwój przestrzenny 4 z 5 badanych wsi oraz w stopniu średnim jednej wsi (Iganie). Ponadto, za rozwój Igań w dużym stopniu odpowiada sąsiedztwo miasta. W pozostałych przypadkach jednostki oddalone są od Siedlec o ok. 30 $\mathrm{km}$. Aby przeciwdziałać ich peryferyjnemu położeniu względem miasta i wzmacniać rolę $\mathrm{w}$ sieci osadniczej regionu za stymulator rozwoju przestrzennego obrano infrastrukturę (komunikacyjna, techniczną) poprzez poprawę jej dostępności i jakości, (tabela 2). 
Tabela 1. Główne czynniki determinujące rozwój przestrzenny analizowanych wsi*

\begin{tabular}{|l|l|l|l|l|l|}
\hline Czynnik determinujący & Dziewule & Hołubla & Iganie & Krzesk & $\begin{array}{l}\text { Wola } \\
\text { Wodyńska }\end{array}$ \\
\hline Zabytkowy charakter wsi & 0 & $\bullet$ & 0 & 0 & 0 \\
\hline Sąsiedztwo miasta & 0 & 0 & $\bullet$ & 0 & 0 \\
\hline Skomunikowanie z miastem & $\bullet$ & $\bullet$ & 0 & $\bullet$ & $\bullet$ \\
\hline Bliskość linii kolejowej & $\bullet$ & 0 & 0 & 0 \\
\hline Dostępność infrastruktury & $\bullet$ & $\bullet$ & $\bullet$ & $\bullet$ & 0 \\
\hline
\end{tabular}

*W toku prac spośród wielu czynników, które wpływają na rozwój wsi, wytypowano te, które w największym stopniu oddziaływały na pozytywne oraz negatywne przemiany analizowanych wsi.

Oznaczenia: $\bigcirc$ - brak wpływu, $\mathbf{O}$ - w niewielkim stopniu, $\mathbf{0}$ - w średnim stopniu, $\bullet$ - w dużym stopniu

\section{Tabela 2. Identyfikacja przemian w poszczególnych miejscowościach}

\begin{tabular}{|c|c|}
\hline Obszar & Identyfikacja przemian \\
\hline Dziewule & $\begin{array}{l}\text { Od początku XX w. układ przestrzenny przekształcił się z widlicy w wielodrożnicę, liczba za- } \\
\text { budowań wzrosła kilkukrotnie. Zmienił się wygląd zabudowy (przejawia cechy architektury } \\
\text { miejskiej), powstały nowe miejsca użyteczności publicznej, zbudowano kościół parafialny. } \\
\text { Jedynym zachowanym elementem historycznym są kapliczki, krzyże przydrożne, drzewa so- } \\
\text { literowe. }\end{array}$ \\
\hline Hołubla & $\begin{array}{l}\text { Na terenie wsi zaszło mało zmian, peryferyjne położenie powoduje, że ludność nie chce osie- } \\
\text { dlać się na tych terenach. Zmiany w wyglądzie obiektów publicznych szczególnie widoczne są } \\
\text { po } 2004 \text { r., ponieważ fundusze unijne pozwoliły na przeprowadzenie remontów takich obiek- } \\
\text { tów jak szkoła, świetlica czy drogi. Istotny jest fakt, że w miejscowości zachował się historyczny } \\
\text { układ ruralistyczny oraz istnieje duży udział zabudowy drewnianej, mała architektura sakralna, } \\
\text { co nadaje wsi unikatowy charakter. Z uwagi na brak presji inwestycyjnej zachowały się frag- } \\
\text { menty alei drzew. }\end{array}$ \\
\hline Iganie & $\begin{array}{l}\text { Z uwagi na położenie w bezpośrednim sąsiedztwie Siedlec, na skutek procesów suburbani- } \\
\text { zacji wieś przekształca się w sypialnię miasta. Zmieniły się usługi oferowane na tym terenie, } \\
\text { funkcja rolnicza zanikła na rzecz funkcji mieszkaniowo-usługowej. Brakuje tu jednak miejsc } \\
\text { integracji i miejsc użyteczności publicznej, a istniejące zabytki niszczeją. }\end{array}$ \\
\hline Krzesk & $\begin{array}{l}\text { Układ Królowej Niwy to niezmiennie ulicówka, na przestrzeni lat widoczne jest zagęszczenie } \\
\text { zabudowy i wydłużenie wsi. Krzesk Majątek przekształcono z zabudowań dworskich w widlicę. } \\
\text { Zwiększyła się liczba zabudowań, nastąpiła zmiana wyglądu domów. Dwór upaństwowiono, } \\
\text { następnie wykupiony został przez dawnych właścicieli i odrestaurowany. Zachowane zostało } \\
\text { historyczne założenie oraz część drewnianych domów. Nastąpiła likwidacja gminy Królowa } \\
\text { Niwa, a wieś należy do gminy Zbuczyn. }\end{array}$ \\
\hline $\begin{array}{l}\text { Wola } \\
\text { Wodyńska }\end{array}$ & $\begin{array}{l}\text { Poprawił się stan materialny mieszkańców, domy i siedliska są obecnie bardziej zadbane. } \\
\text { Zachowany został układ przestrzenny, zabudowa nadal usytuowana jest luźno. Na przestrzeni } \\
\text { XX w. liczba zabudowań nieznacznie wzrosła. Dawny folwark został rozebrany, pozostał zanie- } \\
\text { dbany park podworski wraz z zarastającym kompleksem stawów. Na wsi widoczny jest duży } \\
\text { udział kapliczek. Zamknięto dawną szkołę ze względu na małą liczbę dzieci, obecnie we wsi } \\
\text { brakuje miejsc publicznego użytku. }\end{array}$ \\
\hline
\end{tabular}


W każdej miejscowości odnotowano rozwój przestrzenny zabudowy, co w niektórych wsiach spowodowało przekształcenie pierwotnego układu ruralistycznego $\mathrm{w}$ inny typ (Dziewule, Iganie). Charakterystyczna dla wsi zabudowa drewniana ustępuje miejsca zabudowie murowanej. Podkreślić należy, iż dwie z pięciu przebadanych miejscowości (Hołubla, Wola Wodyńska) charakteryzują się nadal dużym udziałem zabudowy drewnianej. W większości wsi dworskich, majątki do dzisiejszych czasów albo nie przetrwały, albo są w stanie ruiny (Iganie, Wola Wodyńska). Zachowane elementy historyczne (poza dworami) w analizowanych miejscowościach to najczęściej kapliczki. Odnotowano także rozwój miejsc użyteczności publicznej takich jak szkoły, sklepy, świetlice wiejskie. Zieleń w układach ruralistycznych to obecnie głównie pola, łąki oraz lasy. Parki dworskie zachowały się w formie szczątkowej (Iganie, Krzesk, Wola Wodyńska). Obecnie analizowane wsie zatracają swoją pierwotną funkcję rolniczą na rzecz mieszkaniowej czy usługowej (Dziewule, Krzesk, Iganie). Potwierdza się także fakt, że większość mieszkańców wsi podejmuje pracę zarobkową w mieście, w rolnictwie pracuje niewielki odsetek ludności. Na ziemi siedleckiej także można zauważyć rozwój infrastruktury technicznej takiej jak wodociągi czy kanalizacja oraz poprawę jakości dróg, szczególnie w miejscowościach, gdzie widoczny jest duży rozrost zabudowy. Największy rozwój wsi obserwowany jest po okresie wstąpienia Polski do Unii Europejskiej.

\section{Podsumowanie}

Wykonane analizy pokazują że wsie nieustannie ulegają przemianom. Współczesność przyniosła zaburzenie dotychczasowego ładu, zmianę podziałów przestrzennych, przenoszenie funkcji miejskich do wsi czy chaos związany z dynamicznym, często nieskoordynowanym $\mathrm{z}$ elementami zagospodarowania przestrzennego rozwojem infrastruktury technicznej [Fortuna-Antoszkiewicz, Kimic 2007]. Obecnie wieś nie jest już kojarzona wyłącznie z funkcja rolniczą [Szymańska 2013]. Do niedawna izolowane miejscowości wiejskie zostały włączone w globalną sieć [Williams 2002]. Rosnąca zasobność społeczeństwa, łatwiejszy transport, zmiana stylu życia oraz planowanie czasu wolnego powodują większe zainteresowanie wsią. Zachodzące na obszarach wiejskich zmiany mają także negatywny wpływ, bowiem narażają wsie na degradację przestrzenno-krajobrazową [Raszeja 2013].

W toku analiz układów ruralistycznych wykryte zostały następujące prawidłowości:

- powierzchnia zabudowy w badanych wsiach powiatu siedleckiego wzrosła,

- rozrost wsi spowodował przekształcenie układów ruralistycznych,

- dużo terenów rolnych przeznaczonych zostało pod zabudowę zmniejszając tym samym udział terenów otwartych i zaburzając tradycyjny wizerunek wsi,

- współczesny wygląd domów mieszkalnych nie przypomina tych z początków XX w., ponieważ ich kubatury, styl, kolorystyka, wykorzystywany budulec i detal nie wpisują się w tradycję architektoniczną wsi siedleckiej (zanik typowej wsi siedleckiej z zabudową zagrodową i drewnianymi budynkami), 
- nastąpił rozwój miejsc użyteczności publicznej,

- największe zmiany w wyglądzie publicznych terenów we wsiach zauważalne są po wejściu Polski do Unii Europejskiej, a wynikają z uzyskania dofinansowania z funduszy europejskich,

- rozwój wsi uzależniony jest od ich położenia i połączenia komunikacyjnego z miastem, miejscowości peryferyjne mają zahamowany rozwój, natomiast te położone w sąsiedztwie miasta bądź dobrze z nim skomunikowane dynamicznie się rozwijają

- zmiana podstawowych funkcji wsi z rolniczych na mieszkaniowe i usługowe, co spowodowane jest podejmowaniem pracy zarobkowej w mieście, i niewielki odsetek pracujących w rolnictwie.

Przeznaczenie obszarów krajobrazu otwartego na cele inwestycyjne, czy zerwanie z rolniczą tradycją poprzez wprowadzenie zabudowy o funkcji nierolniczej pociaga za sobą konsekwencje przestrzenne. Wszak tereny otwarte, użytki rolne stanowią istotne wyróżniki krajobrazu wiejskiego. Nadawanie im wtórnych funkcji, przeznaczanie pod zabudowę przyczynia się do degradacji przestrzeni. W związku z tym, dynamiczne przemiany notowane na obszarach wiejskich powodują konieczność odrębnego podejścia do kształtowania krajobrazu kulturowego wsi, dostosowanego do jej specyfiki. Zalecane jest tworzenie planów miejscowych, które mogą pozytywnie wpłynąć na ochronę charakteru i tożsamości wsi wraz z zachowaniem historycznych układów ruralistycznych. Istnieje także potrzeba zachowania zwartego charakteru zabudowy, niedopuszczenie do przewagi zabudowy nad terenami otwartymi oraz ochrona istniejących dominant krajobrazowych i dziedzictwa kulturowego.

\section{Bibliografia}

Bański J., 2002, Geografia wsi - nowa dyscyplina badawcza polskiej geografii, „Przegląd Geograficzny", 74, 3, s. 367-379.

Bański J., 2010, Przemiany polskiej wsi, IGiPZ PAN, Warszawa.

Bański J., 2011, Wieś w badaniach geograficznych - ewolucja badań i przegląd koncepcji obszaru wiejskiego, [w:] M. Halamska (red.), Wieś jako przedmiot badań naukowych, Wydawnictwo Naukowe Scholar, Warszawa.

Czerwiński T., 2001, Chałupy chtopskie na pótnocnym Mazowszu i ich wyposażenie w drugiej połowie XIX oraz na poczatku XX wieku, Dziedzictwo kulturowe Mazowsza. Archeologia Architektura - Etnologia, Mazowiecki Ośrodek Badań Naukowych im. Stanisława Herbsta, Warszawa. 
Fortuna-Antoszkiewicz B., Kimic K., 2007, Negatywne przekształcenia krajobrazu terenów wiejskich Mazowsza, „Przyroda i miasto”, 10, Wydawnictwo SGGW, Warszawa, s. 11-18.

Gorlach K., 2004, Socjologia obszarów wiejskich. Problemy i perspektywy, Wydawnictwo Naukowe Scholar, Warszawa.

Grabski W., 1936, System socjologii wsi. Składniki wsi, „Roczniki Socjologii Wsi. Studia i Materiały", 1.

Halamska M., 2011, Wiejskość jako kategoria socjologiczna, „Wieś i Rolnictwo”, 1, 150, s. 37-55.

Heffner K., 2010, Wieś jako przedmiot badań w gospodarce przestrzennej. Ewolucja zagospodarowania przestrzeni wiejskiej w Polsce. Referat wygłoszony na konferencji: Wieś jako przedmiot badań naukowych na poczatku XXI wieku, EUROREG, Uniwersytet Warszawski.

Jarosz M., Kamińska-Szmaj I. , 2001, Słownik Wyrazów Obcych, Wydawnictwo Europa, Wrocław.

Jezierska-Thöle A., 2013, Modele rozwoju obszarów wiejskich w ujęciu teoretycznym, [w:] M.Wójcik (red.), Regionalny wymiar przemian polskiej wsi - aspekty przestrzenno-ekonomiczne, „Studia Obszarów Wiejskich”, 34, PTG, IGiPZ PAN, Warszawa, s. 23-37.

Kondracki J., 2009, Geografia regionalna Polski, Wydawnictwo Naukowe PWN, Warszawa.

Mikulski J., 1935, Powiat Siedlecki. Ziemia, wody, człowiek, [w:] Cz. Górski (red.), Powiat Siedlecki, Siedlce.

Nowak P., 2012, Rozwój obszarów wiejskich w Polsce po integracji z Unia Europejska w opinii lokalnych elit, Wydawnictwo Uniwersytetu Jagiellońskiego, Kraków.

Podedworna H., 2006, Wieś jako przestrzeń konsumpcji i produkt rynkowy, „Roczniki Socjologii Wsi", 27, s. 153-160.

Przestrzeń życia Polaków, 2014, raport opracowany przez zespół niezależnych ekspertów z inspiracji Prezydenta RP Bronisława Komorowskiego, http://www.sarp.org.pl/ pliki/2014_55475382d735c-przestrzen_zycia_polakow.pdf, [dostęp dnia: 20.01.2017].

Raszeja E., 2013, Ochrona krajobrazu w procesie przeksztatceń obszarów wiejskich, Wydawnictwo Uniwersytetu Przyrodniczego w Poznaniu, Poznań.

Rosner A. (red.), 2007, Zróżnicowanie poziomu rozwoju społeczno-gospodarczego obszarów wiejskich a zróżnicowanie dynamiki przemian, IRWiR PAN, Warszawa. 
Studziński J., 2010, Łuszków. Kwestia zasadności wpisu do rejestru zabytków układu osadniczego wobec braku rozpoznania historycznego, „Kurier Konserwatorski”, 6, s. 16-21.

Szmit K., bd., XIX-wieczne dwory Pótnocnego Mazowsza $i$ ich wptyw na ksztattowanie życia mazowieckiej wsi na podstawie majątku Klice,

http://historyzm.pl/biblioteka/klice/dwory_klice. pdf.

Szulc H., 1995, Morfogeneza osiedli wiejskich w Polsce, „Prace Geograficzne”, 163, IGiPZ PAN, Wydawnictwo Continuo, Wrocław.

Szymańska D., 2013, Geografia osadnictwa, Wydawnictwo Naukowe PWN, Warszawa.

Tkocz J., 1998, Organizacja przestrzenna wsi w Polsce, Wydawnictwo Uniwersytetu Śląskiego, Katowice.

Wieczorkiewicz W., 1995, Planowanie przestrzenne osadnictwa wiejskiego, Wydawnictwo SGGW, Warszawa.

Wilkin J., 2011, Jak zapewnić rozwój wsi w warunkach zmniejszającej się roli rolnictwa?, [w:] M.Halamska (red.), Wieś jako przedmiot badań naukowych, Wydawnictwo Naukowe Scholar, Warszawa.

Williams D.R., 2002, Leisure identities, globalization and the politics of place, "Journal of Leisure Research", 4, s. 351-367.

Wiśniewska M., 1984, Planowanie osiedli wiejskich, Arkady, Warszawa.

Wójcik M., 2012, Geografia wsi w Polsce. Studium zmiany podstaw teoretyczno-metodologicznych, Wydawnictwo Uniwersytetu Łódzkiego, Łódź.

Zaborski B., 1926, O ksztattach wsi w Polsce i ich rozmieszczeniu, „Prace Komisji Etnograficznej Polskiej Akademii Umiejętności", 1, Kraków.

Zaniewska H., Pawłat-Zawrzykraj A., Gloza-Musiał H., 2000, Zagospodarowanie przestrzenne i zabudowa wsi, Wydawnictwo SGGW, Warszawa.

\section{Źródła internetowe}

http://stat.gov.pl/bdl/ (dostęp: 04.2017)

http://www.mapywig.org (dostęp: 03.2017)

http://mapy.geoportal.gov.pl (dostęp: 03.2017) 


\section{The transformation of rural layouts in East Mazovia as examplified by villages in Siedlce county}

\section{ABSTRACT}

The aim of this study was to identify the main elements of rural layouts and the changes taking place in the composition and spatial development of Mazovian villages in the twentieth and twenty-first century through analysis of selected villages in Siedlce county. First a review of literature was carried out with focus on that concerning rural systems, changes to the countryside and the features of Mazovian villages. Next, after an analysis of Siedlce county, villages were selected for research concerning changes in rural layout from the interwar period to the present. The analysis was based on topographic maps, site visits and written sources. The results confirmed that the rural layouts have changed significantly. The main reasons for the transformation are lifestyle change and weakening of the role of agriculture in rural areas. These changes are exposing villages to degradation of space and the loss of their original features, therefore measures aimed at preventing negative transformations are advisable. The article is based on a 2016 master's thesis.

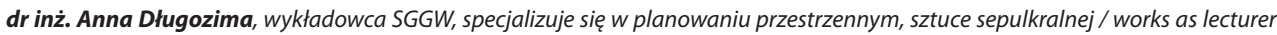
in the SGGW, by profession is the specialist in the spatial planning, funerary art, kontakt / contact: Szkoła Główna Gospodarstwa Wiejskiego w Warszawie, Katedra Sztuki Krajobrazu, ul. Nowoursynowska 166, 02-787 Warszawa, e-mail:ania.dlugozima@gmail.com

mgr inż. Marlena Bierkat, absolwentka gospodarki przestrzennej SGGW, pracownik administracji publicznej / graduate of spatial management SGGW, civil servant, kontakt / contact: Mazowieckie Biuro Planowania Regionalnego w Warszawie, Oddział Terenowy w Siedlcach, ul. Pułaskiego 19/21, 08-110 Siedlce, e-mail: mbierkat@mbpr.pl 